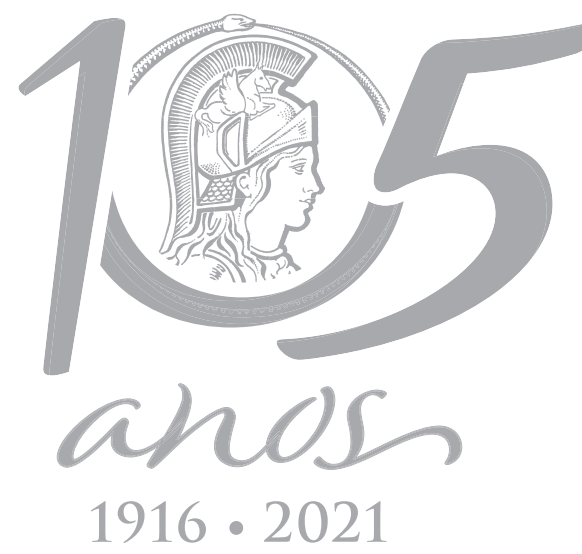

\title{
ECOSYSTEM
}

\section{Trophic ecology of Loricariichthys anus (Valenciennes, 1835), (Loricariidae: Loricariinae) in a subtropical reservoir, Rio Grande do Sul, Brazil}

\author{
FABIANO CORRÊA, THIAGO S. TUCHTENHAGEN, JUVÊNCIO POUEY, SÉRGIO R.N. \\ PIEDRAS \& EDSON F. DE OLIVEIRA
}

\begin{abstract}
The paper describes the trophic ecology of the Loricariichthys anus in a subtropical reservoir. The specimens were collected in the reservoir of the Chasqueiro stream, in Rio Grande do Sul, Brazil. The digestive tract of each specimen was removed for the analysis of the contents and definition of the diet. The Index of Relative Importance (IRI) was used to estimate which types of prey were most important. The diet of the L. anus population was compared among different water levels, seasons, ontogenetic classes, feeding strategy and fractional trophic level. There was a significant difference between hydrological levels, although no significant variation was found in the composition of the $L$. anus diet between seasons or among ontogenetic classes. This is probably due to the fact that $L$. anus is a specialist species, with a diet composed predominantly of fine particulate material. At the trophic level, the diet of the species was based on detritus, which reflects the morphology of its body and digestive tract. Considering these findings, L. anus may be a keystone species in the Chasqueiro reservoir and its conservation, in both natural and artificial environments, is necessary for the bottom-up management of this and other Neotropical ecosystems.
\end{abstract}

Key words: Diet, Neotropical region, Lagoa Mirim system, Siluriformes.

\section{INTRODUCTION}

In the aquatic environments of the Neotropical region, the hydrological cycle is one of the principal environmental forces that influence the availability of feeding resources, leading to changes in the trophic level of the fish, and modifying the structure of the local food web (Junk 1980, Garcia et al. 2017, Quirino et al. 2017). The construction of reservoirs is one of the principal types of anthropogenic modification that can alter the hydrological cycle of a river basin (Bailly et al. 2016), modifies primary productivity and changes both abiotic (e.g., dissolved oxygen, luminosity) and biotic variables (e.g., predation, reproduction), as well as fish feeding patterns and these impacts cause disturbances throughout the aquatic ecosystem (Winemiller 1989, Ferreira et al. 2014, Corrêa et al. 2015, Winemiller et al. 2016).

In addition to measuring intraspecific trophic interactions, studies of trophic ecology provide an important systemic perspective on the processes associated with feeding patterns (Winemiller 1990, Roach et al. 2014, Peralta-Maraver et al. 2017). Quirino et al. (2017) concluded that changes in the composition of the diet of a fish population are associated with seasonal and spatial shifts in the distribution of resources, which reinforces the need to segregate 
feeding strategies, ontogenetic variations in the diet, and the trophic position of each species. Gerking (1994) notes that, while most species adopt a specific type of feeding strategy (e.g., specialist or generalist), environmental factors may force them to feed on resources outside the normal range of their trophic level.

One other major feature of trophic ecology is that many fish species exhibit marked ontogenetic variation in feeding behavior, which is driven, in particular, by shifts in morphological characteristics, such as the buccal apparatus, and body shape and structure, as well as the anatomy of the digestive system (Youson \& AlMahrouki 1999, Hahn et al. 2000, Giora et al. 2005, Vital-Rodriguéz et al. 2017). The ontogenetic variation found in some fish species results in shifts in trophic level and the position of the species in the local food web over the course of its life cycle. The fractional trophic level of the organisms in a food web is an important metric that reveals how changes in the system affect its energy flow patterns and, in turn, the availability of food, which allows fish to migrate between distinct trophic levels (Pauly \& Christensen 2000, Stergiou \& Karpouzi 2002, Wesner \& Belk 2015).

Basal groups such as the species of the family Loricariidae that have iliophagous or detritivorous feeding habits, are prominent regulators of the energy flow in aquatic systems, participating directly in the nutrient cycling through their consumption of fine particulate matter (Bowen 1983, Silva et al. 1997, Peretti \& Andrian 2004, Corrêa \& Piedras 2008, Delariva et al. 2013). When these detrivorous fishes are preyed on by piscivores this material ends up being transferred to higher trophic levels (Garcia et al. 2007, 2017, Corrêa et al. 2012, Oliveira et al. 2014), favoring the energetic increment of the predators at the top of the food chain. Loricarrids thus constitute an important trophic link that promotes the recycling of nutrients, in addition to linking the different trophic levels in the food web (Fugi et al. 2001, Peretti \& Andrian 2004, Garcia et al. 2007, Souto et al. 2011).

The Loricariidae is a highly diverse catfish family endemic to Central and South America (Lujan et al. 2012, Zawadzki et al. 2015, 2018, Reis et al. 2016). The locariid species Loricariichthys anus (Valenciennes, 1835) is widely distributed in the Neotropical region, occurring in Argentina, Uruguay, and Brazil (Reis \& Pereira 2000, Malabarba et al. 2013). This species is an important resource for subsistence and smallscale fisheries operating on the coastal lagoons of southern Brazil (Petry \& Schulz 2000, Corrêa et al. 2015, Fontoura et al. 2016). This fishery resource has been exploited in an increasingly systematic manner in recent years due to its high value and the growing demand for its meat. Despite the widespread distribution of $L$. anus, and its considerable ecological and economic importance for the aquatic ecosystems of the Austral region of Brazil, few trophic data are available for this species. In the present study, the trophic ecology of $L$. anus was investigated in a reservoir to evaluate fundamental ecological features, such as the influence of the water level, seasonal variation, ontogenetic development on the species' diet, in addition to estimating the feeding strategy and estimating its fractional trophic level. The data compiled in the study provide important insights for the development of effective conservation and management strategies for this species in the coastal lagoon systems of the southern extreme of Brazil.

\section{MATERIALS AND METHODS}

\section{Study area}

The hydrographic basin of the Chasqueiro stream (Arroio Chasqueiro) is located at the western extreme of the Lagoa Mirim lagoon system, in the municipality of Arroio Grande, 


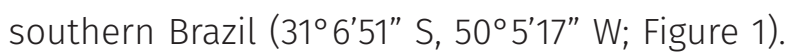
This basin is formed by two principal streams (Chasqueiro and Chasqueirinho) and a reservoir. The area upstream from the reservoir is 248.4 $\mathrm{km}^{2}$, being formed by both the Chasqueiro $\left(114.84 \mathrm{~km}^{2}\right)$ and Chasqueirinho $\left(133.58 \mathrm{~km}^{2}\right)$ basins. The Chasqueiro reservoir has an area of 1,800 ha, which is used mainly to support the irrigated cultivation of rice (Sondotécnica 1976). At sampling site 1, the margins of the reservoir are dominated by planted pasture, used for grazing, and some large boulders, with a mainly sandy substrate (73.6\%), followed by clay $(14.0 \%)$ and silt (12.4\%), with some large stones. The margin at site 2 is also dominated by pasture, with a sandy substrate (73.5\%), clay (14.0\%) and silt (12.2\%), for a detailed description of the characteristics of the study areas, see Corrêa et al. $(2014,2015)$.

\section{Fish sampling and dietary analysis}

The fish specimens were collected monthly between August 2012 and July 2013 (SISBIO license no. 34389-1) at the two sampling points in the Chasqueiro reservoir, using: (a) a gillnet, $75 \mathrm{~m}$ in length with 10, 20,30,40, and $50 \mathrm{~mm}$ meshes, which was set for $24 \mathrm{~h}$ and checked for fish every 12h, and (b) a 5-m seine net, $5 \mathrm{~m}$ in length and 2.25 high, with a $5 \mathrm{~mm}$ mesh. The gillnet was used to sample the deeper parts

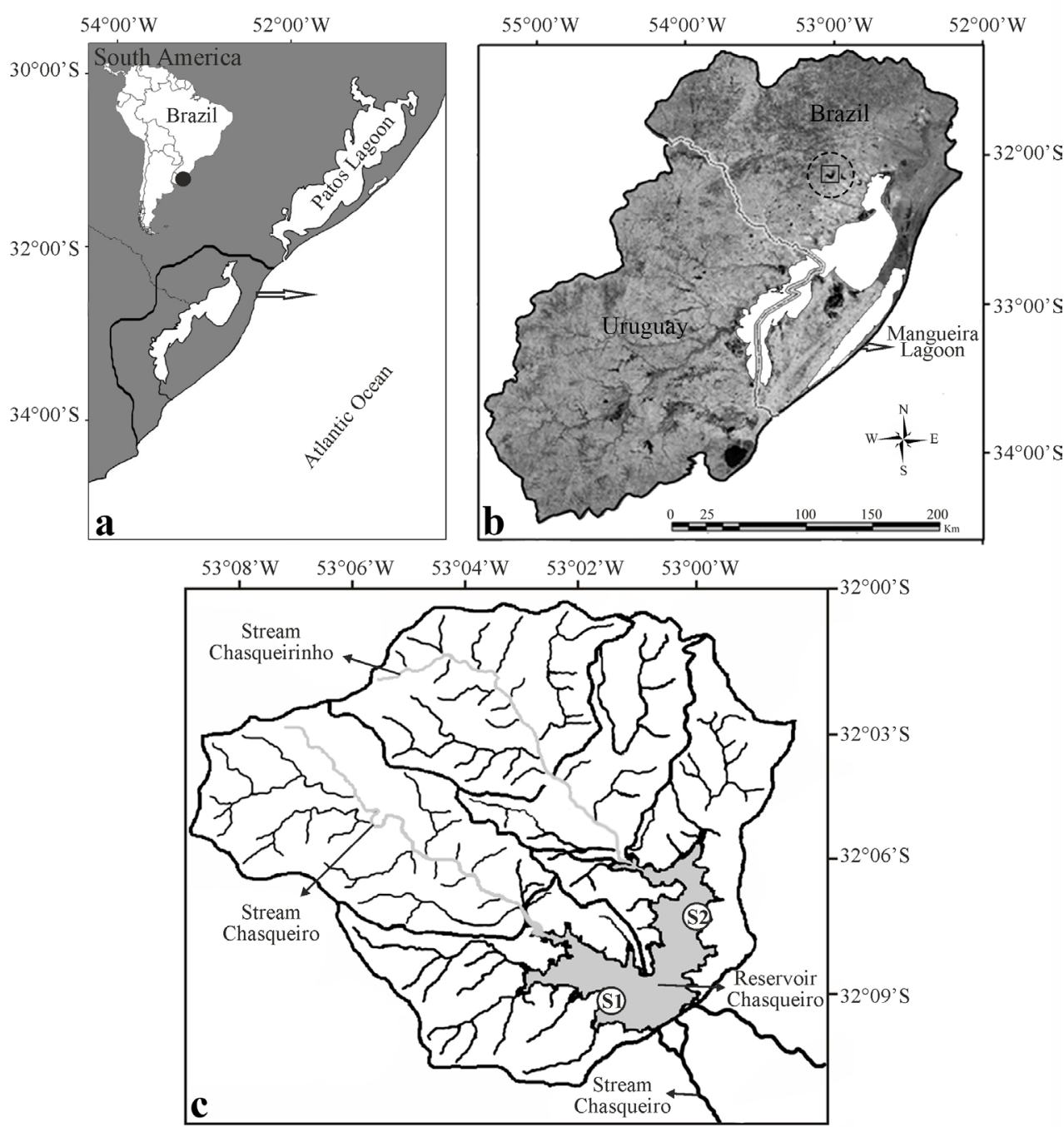

Figure 1. (a) Location of South America, (b) hydrographic system of Lagoa Mirim, with indication of the hydrographic basin of the Arroio Chasqueiro by the black dot and (c) hydrographic basin of the Arroio Chasqueiro with the sampling points 1 and 2, Arroio Grande municipality, Southern Brazil. 
of the reservoir (depths of 1.0-2.5 m) in order to capture larger individuals (> $200 \mathrm{~mm}$ ), while the seine net was used at the margins of the reservoir, with the net being deployed five times per point. The specimens collected were placed in plastic bags, anesthetized with a Eugenol solution (Keene et al. 1998), tagged, and then fixed in $5 \%$ formaldehyde for $24 \mathrm{~h}$ before being transferred to $70 \%$ alcohol for storage. Voucher specimens were deposited in the ichthyological collection of the Universidade Federal do Rio Grande (ICFURG \#0045).

For the dietary study, the individuals were eviscerated and the anterior third of the intestine was examined following Fugi et al. (1996). The intestine was analyzed because, in the loricariids, the stomach is typically an accessory organ for respiration (Silva et al. 1997). The specimens were subsequently identified to the lowest possible taxonomic level based on the available literature, for example, algae (Menezes \& Bicudo 2006), insects (Costa et al. 2006), and macroinvertebrates (Mugnai et al. 2010). The sediment or detritus was classified as Fine Particulate Matter (FPM). The different dietary items were evaluated according to the following metrics, proposed by Hyslop (1980): (a) frequency of occurrence (\% F), percentage of individuals in which a given food item was found, (b) numerical frequency $(\% \mathrm{~N})$, that is, the percentage of the item in relation to the total abundance of all items found in the digestive tract, and (c) the area of the item (\% A), that is, the percentage area of the food item in relation to the total area of all the food items found, where the food item was spread evenly on a millimeter-grid plate. These metrics were combined to calculate the Index of Relative Importance of Pinkas et al. (1971) using the formula: $|R|=\% F *(\% N+\% A)$, the result of which is transformed into a percentage (Cortés 1997).

\section{Effects of water level, seasonal variation, and ontogenetic development on the $L$. anus diet}

For analysis, the reservoir level was classified as low or high, with the water level data being obtained from the meteorological station of the COODIC (Cooperative of the Landowners of the Chasqueiro Reservoir Irrigation District), in the southern extreme of Brazil (Figure 2). The diet was analyzed in relation to the low or high water level, the seasons (Winter, Spring, Summer, and

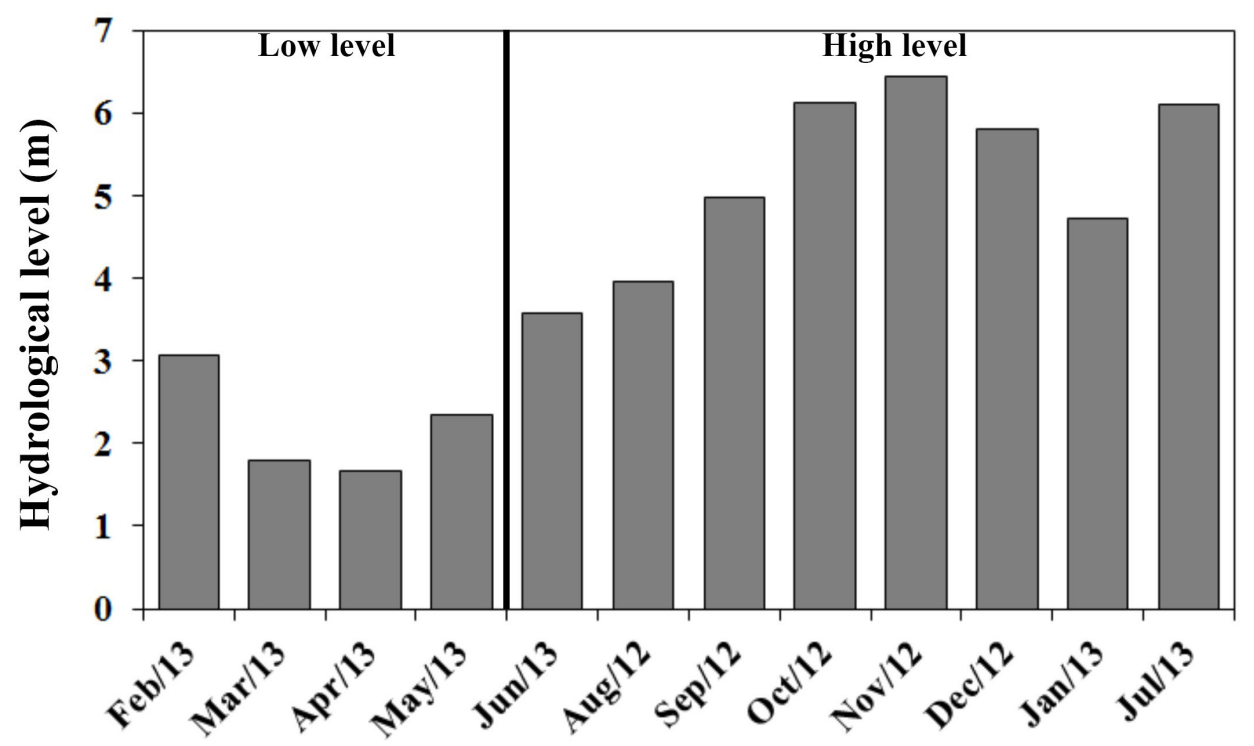

Study of period
Figure 2. Hydrological level among the studied period, the left the low level and the right the high level, in the Chasqueiro reservoir, southern Brazil. 
Autumn), which are well defined in subtropical regions (Garcia et al. 2001), and for four size classes (Total Length or $\mathrm{TL}$ ) were established for the ontogenetic analysis (Martins et al. 2017) class $1(T L=0-100 \mathrm{~mm})$, class $2(101-200 \mathrm{~mm})$, class 3 (201-300 mm), and class 4 (301-400 mm). A semi-parametric permutational multivariate analysis of variance (PERMANOVA) was used to verify the significance of the variation in the $L$. anus diet between low and high water levels, and among seasons and ontogenetic classes, using the Bray-Curtis similarity index with 9999 permutations (Anderson 2005), with pairwise a posteriori comparisons between factors that had significant differences $(p<0.05)$. An analysis of the minimum percentage similarity (SIMPER) was also used to evaluate which dietary item contributed most to the dissimilarity among the seasons given that this variable presented significant variation (Clarke 1993). These analyses were run in the PRIMER statistical package (version 6; PRIMER-E, Plymouth, UK).

\section{Feeding strategy and trophic position}

The graphic method of Amundsen et al. (1996) was used to evaluate the feeding strategy of $L$. anus, with the frequency of occurrence on the abscissa and the prey abundance $(\mathrm{Pi})$ on the ordinate axis. The value of $\mathrm{Pi}$ is defined as the relative abundance of an item in comparison with the total number of items, considering only the guts that contained item $i$, and is calculated by the formula: $\mathrm{Pi}=(\Sigma \mathrm{Si} / \Sigma \mathrm{St}) \times 100$, where $\mathrm{Si}=$ the sum of item $i$, and $S t=$ the total number of items in the guts containing item $i$.

The fractional trophic levels were estimated from the IRI\% values for the feeding categories (trophic level) recorded in the different seasons, using the TrophLab software (Pauly et al. 2000). Data available in the TrophLab software were used to determine the trophic position of the prey species (Pauly et al. 2000), where the estimate expresses the position of the organism in the food chain (Stergiou \& Karpouzi 2002, Pauly \& Christensen 2000, Pauly \& Palomares 2000) based on the formula:

$$
\begin{gathered}
G \\
\text { TROPHi }=1+\sum \text { DCij * TROPHj } \\
j=1
\end{gathered}
$$

where: $\mathrm{TROPHi}=$ fractional trophic level of species $i, \mathrm{TROPH}$ = fractional trophic level of prey $j, \mathrm{DC} i j=\%$ relative importance of $j$ in the diet of $i$, and $G=$ relative importance (IRI\%) of the prey.

In this method (Pauly \& Palomares 2000), the trophic levels of the prey species are considered to be measurable entities with values of 1.0 (primary producers and detritus/sediment), 2.0 (herbivores), 3.0 (omnivores), and 4.0-5.0 (carnivores/piscivores). A parametric one-way ANOVA was used to evaluate whether there was significant variation in the trophic level of the species by season, based on the assumptions of normality of the Jarque-Bera test (Jarque \& Bera 1987, Zar 1996), with a significance level of $0.05 \%$. To check for univariate trophic interactions of the species in relation to the water level, season, and size classes, bipartite graphs were plotted and adjusted to the highest degree of feeding importance, using the matrix of the IRI\% values for the feeding categories. This procedure used the BIPARTITE algorithm of the R software, version 3.2.3 (Dormann et al. 2009, Dormann \& Strauss 2014).

\section{RESULTS}

\section{Effects of the water level on the $L$. anus diet}

A total of 62 L. anus specimens were analyzed. These specimens had a mean Total Length (TL) of $319.4 \pm 10.2 \mathrm{~mm}$ and Total Weight (TW) of 
$225.4 \pm 14.9$ g. Most (41) of the specimens were collected at low water, with a mean length of $315 \pm 13.7 \mathrm{~mm}$ and weight of $213.9 \pm 18.2 \mathrm{~g}$, while 21 specimens were collected at high water (mean $\mathrm{TL}=327.5 \pm 14.1 ; \mathrm{TW}=247.7 \pm 26.1 \mathrm{~g}$ ). The PERMANOVA did not indicate any significant variation in the composition of the diet related to the level of the water $(\mathrm{df}=1$; pseudo- $\mathrm{F}=1.91 ; \mathrm{p}=0.11$ ). It is important to note, however, that the highest number of trophic links (15) was recorded during low water, when $L$. anus fed primarily on FPM $($ IRI\% $=49.5)$ and plant matter $(30.9 \%)$, with some insects of the order Ephemeroptera (5.7\%). A total of 13 trophic links were recorded at high water, when FPM $(I R I \%=53.3)$ and plant matter (29.5\%) also contributed most to the diet L. anus, followed by the Nematoda, with 1.1\% (Table I).

\section{Effects of seasonal variation on the $L$. anus diet}

The results of the PERMANOVA indicate significant variation among the seasons ( $\mathrm{df}=3$, pseudo- $F$ = 4.15; $p=0.001$ ). The smallest number of food items were consumed during the winter, when FPM was the most important item (IRI\% = 89.2), followed by plant matter (4.76). In the spring, the importance of FPM declined (IRI\% = 38.3) while the insects of the order Ephemeroptera became a prominent component of the diet $(I \mathrm{RI} \%=26.9)$. In the summer, organic matter $(I R I \%=40.3)$ and plant matter (40.1), while in the autumn, FPM increased $(I R I \%=52.4)$, and plant matter (36.3) was still prominent, but decreased slightly (Table II), and the pairwise test among seasons are shown in Table III. The variation among the seasons was confirmed by the SIMPER analysis, in which FPM was the principal item contributing to the general dissimilarity. The highest mean global similarity was recorded between the autumn and the spring (72.2), while the lowest mean global dissimilarity (50.3) was recorded between the summer and winter (Table IV).

\section{Effects of ontogenetic variation on the $L$. anus diet}

The PERMANOVA did not indicate any significant variation among ontogenic classes $(\mathrm{df}=3$, pseudo- $F=0.52 ; p=0.95$ ), although certain shifts in the diet were observed, with body size class 2 having the smallest number of trophic links (seven), while class 3 had the largest number of links (17), including the consumption of Acari, Ephemeroptera, Nematoda, and seeds (Table V). Fine particulate matter was the most important item for all body size classes, varying from an IRI\% of 60.3 for the smallest individuals to 34.0 in the largest ones. It is important to note, however, that the largest individuals consumed Thecamoeba $(|R| \%=26.6)$, a resource used exclusively by size class 4 (Table V). The bipartite plots of the variation in water levels, seasons, and ontogenetic classes are shown in Figure 3.

\section{Feeding strategy and trophic position}

The graphic method of Amundsen indicates that the $L$. anus population followed a specialist feeding strategy, consuming a large proportion of fine particulate matter, which was consumed by more than half of the specimens analyzed, despite the reduced abundance of species, which indicates a relatively high phenotypic component. Smaller proportions of other items, such as Chelicerata, Nematoda, and Protozoa, were also included eventually in the L. anus diet (Figure 4). No significant variation was observed in the trophic position of the species among seasons (ANOVA: $F=0.14 ; p=0.94$ ). The lowest mean trophic levels were recorded in the winter $(2.09 \pm 0.10)$ and spring $(2.03 \pm 0.60)$, while the highest mean trophic level was recorded in the summer $(2.72 \pm 0.30)$. 
Table I. Frequency of occurrence (\%F), numeric frequency $(\% \mathrm{~N})$, area $(\% \mathrm{~A})$ and index of relative importance (\%IRI) for food items consumed by L. anus collected during the low and high hydrological level in the Chasqueiro reservoir, southern Brazil.

\begin{tabular}{|c|c|c|c|c|c|c|c|c|}
\hline \multirow[t]{2}{*}{ Food items } & \multicolumn{4}{|c|}{ Low level $(n=21)$} & \multicolumn{4}{|c|}{ High level $(n=41)$} \\
\hline & $\% F$ & $\% N$ & $\% A$ & \%IRI & $\% \mathrm{~F}$ & $\% N$ & $\% A$ & \%IRI \\
\hline Acari & 4.9 & 0.3 & 0.1 & $<0.1$ & & & & \\
\hline Algae filamentous & 4.9 & 13.5 & 1.2 & 0.9 & 9.5 & 6.4 & 0.6 & 0.8 \\
\hline Sand & 26.8 & 0.9 & 6.4 & 2.6 & 14.3 & 0.7 & 1.2 & 0.3 \\
\hline Cladocera & 2.4 & 0.9 & 0.2 & $<0.1$ & & & & \\
\hline Copepoda & 2.4 & 0.8 & 0.2 & $<0.1$ & & & & \\
\hline Diptera (adult) & & & & & 4.8 & 0.5 & 0.0 & $<0.1$ \\
\hline Ephemeroptera (adult) & 24.4 & 3.6 & 14.1 & 5.7 & & & & \\
\hline Hemiptera (adult) & & & & & 4.8 & 0.2 & 0.0 & $<0.1$ \\
\hline Coleoptera (larva) & 22.0 & 7.4 & 2.0 & 2.7 & 4.8 & 3.0 & 0.2 & 0.2 \\
\hline Diptera (larva) & & & & & 9.5 & 0.5 & 0.5 & 0.1 \\
\hline Fine particulate matter & 75.6 & 2.4 & 47.2 & $49.5^{\star}$ & 76.2 & 3.7 & 51.9 & $53.3^{\star}$ \\
\hline Organic matter & 14.6 & 9.6 & 5.9 & 3.0 & 28.6 & 19.7 & 19.8 & 14.2 \\
\hline Vegetable matter & 43.9 & 40.6 & 12.8 & $30.9^{*}$ & 28.6 & 59.2 & 22.7 & $29.5^{\star}$ \\
\hline Nemotoda & & & & & 19.0 & 2.5 & 2.0 & 1.1 \\
\hline Ostracoda & 4.9 & 0.3 & 0.1 & $<0.1$ & & & & \\
\hline Palaemonetes argentinus & 2.4 & 0.1 & 0.4 & $<0.1$ & & & & \\
\hline Crustcean remains & 4.9 & 2.0 & 2.8 & 0.3 & 4.8 & 1.1 & 0.4 & 0.1 \\
\hline Insect remains & & & & & 4.8 & 0.2 & 0.4 & $<0.1$ \\
\hline Seed & 14.6 & 11.8 & 5.5 & 3.4 & 4.8 & 2.3 & 0.2 & 0.1 \\
\hline Tecameba & 9.8 & 5.9 & 1.1 & 0.9 & & & & \\
\hline * Food items larger importance & & & & & & & & \\
\hline
\end{tabular}


Table II. Frequency of occurrence (\%F), numeric frequency $(\% \mathrm{~N})$, area $(\% \mathrm{~A})$ and index of relative importance (\%IRI) for food items consumed by L. anus collected during the low and high hydrological level in the Chasqueiro reservoir, southern Brazil.

\begin{tabular}{|c|c|c|c|c|c|c|c|c|c|c|c|c|c|c|c|c|}
\hline & \multicolumn{4}{|c|}{ Winter $(n=8)$} & \multicolumn{4}{|c|}{ Spring $(n=10)$} & \multicolumn{4}{|c|}{ Summer $(n=24)$} & \multicolumn{4}{|c|}{ Autumn $(n=20)$} \\
\hline & $\% F$ & $\% N$ & $\% A$ & \%IRI & $\% F$ & $\% N$ & $\% A$ & \%IRI & $\% F$ & $\% N$ & $\% A$ & \%IRI & $\% F$ & $\% N$ & $\% A$ & \%IRI \\
\hline Acari & & & & & & & & & & & & & 8.3 & 0.5 & 0.1 & $<0.1$ \\
\hline $\begin{array}{c}\text { Algae } \\
\text { filamentous }\end{array}$ & & & & & 10.0 & 32.2 & 2.8 & 4.7 & 10.0 & 3.2 & 0.3 & 0.4 & 4.2 & 2.2 & 0.5 & 0.1 \\
\hline Sand & 12.5 & 2.1 & 2.9 & 0.5 & 35.0 & 1.3 & 8.2 & 4.5 & 20.0 & 0.7 & 1.2 & 0.4 & 16.7 & 0.5 & 3.6 & 0.7 \\
\hline Cladocera & & & & & & & & & & & & & 4.2 & 1.3 & 0.2 & 0.1 \\
\hline Copepoda & & & & & & & & & & & & & 4.2 & 1.2 & 0.2 & 0.1 \\
\hline Diptera (adult) & & & & & & & & & 10.0 & 0.7 & 0.1 & 0.1 & & & & \\
\hline $\begin{array}{l}\text { Ephemeroptera } \\
\text { (adult) }\end{array}$ & & & & & 50.0 & 8.6 & 31.5 & $26.9^{*}$ & & & & & & & & \\
\hline $\begin{array}{l}\text { Hemiptera } \\
\text { (adult) }\end{array}$ & 12.5 & 2.1 & 0.2 & 0.2 & & & & & & & & & & & & \\
\hline $\begin{array}{l}\text { Coleoptera } \\
\text { (larva) }\end{array}$ & 12.5 & 27.1 & 1.1 & 2.9 & 15.0 & 1.1 & 0.2 & 0.3 & & & & & 25.0 & 10.5 & 2.5 & 3.3 \\
\hline Diptera (larva) & & & & & & & & & 20.0 & 0.7 & 0.8 & 0.3 & & & & \\
\hline $\begin{array}{c}\text { Fine particulate } \\
\text { matter }\end{array}$ & 100.0 & 16.7 & 90.8 & $89.2^{\star}$ & 80.0 & 3.0 & 32.7 & $38.3^{*}$ & 50.0 & 1.8 & 29.2 & 16.9 & 75.0 & 2.1 & 67.5 & $52.4^{*}$ \\
\hline Organic matter & & & & & 25.0 & 22.7 & 9.0 & 10.6 & 60.0 & 30.2 & 31.3 & $40.3^{*}$ & 4.2 & 0.1 & 2.5 & 0.1 \\
\hline Vegetable matter & 12.5 & 43.8 & 2.1 & 4.8 & 35.0 & 18.8 & 7.1 & 12.1 & 40.0 & 58.2 & 33.3 & $40.1^{*}$ & 50.0 & 57.8 & 14.4 & $36.3^{*}$ \\
\hline Nemotoda & 25.0 & 8.3 & 3.0 & 2.3 & & & & & 20.0 & 2.5 & 2.5 & 1.1 & & & & \\
\hline Ostracoda & & & & & 5.0 & 0.2 & 0.0 & $<0.1$ & & & & & 4.2 & 0.4 & 0.1 & 0.1 \\
\hline $\begin{array}{c}\text { Palaemonetes } \\
\text { argentinus }\end{array}$ & & & & & 5.0 & 0.2 & 1.0 & 0.1 & & & & & & & & \\
\hline $\begin{array}{c}\text { Crustcean } \\
\text { remains }\end{array}$ & & & & & 10.0 & 4.8 & 6.2 & 1.5 & 10.0 & 1.8 & 0.7 & 0.3 & & & & \\
\hline Insect remains & & & & & & & & & 10.0 & 0.4 & 0.7 & 0.1 & & & & \\
\hline Seed & & & & & 5.0 & 1.9 & 0.3 & 0.1 & & & & & 25.0 & 17.9 & 7.4 & 6.4 \\
\hline Tecameba & & & & & 10.0 & 5.4 & 1.0 & 0.9 & & & & & 8.3 & 5.5 & 0.9 & 0.5 \\
\hline $\begin{array}{l}\text { * Food } \\
\text { items larger } \\
\text { importance }\end{array}$ & & & & & & & & & & & & & & & & \\
\hline
\end{tabular}

Table III. The pairwise test among the seasons of $L$. anus diet, collected in the Chasqueiro reservoir, southern Brazil.

\begin{tabular}{|c|c|c|}
\hline Grups & $\boldsymbol{t}$ & $\boldsymbol{p}$ \\
\hline Summer $\times$ Autumn & 1.701 & 0.035 \\
\hline Summer $\times$ Winter & 2.256 & 0.009 \\
\hline Summer $\times$ Spring & 2.426 & 0.004 \\
\hline Autumn $\times$ Winter & 1.884 & 0.016 \\
\hline Autumn $\times$ Spring & 1.603 & 0.067 \\
\hline Winter $\times$ Spring & 2.857 & 0.004 \\
\hline
\end{tabular}


Table IV. Similarity percentages (SIMPER) using for avalue the dissimilarity among the seasons of the year in the feeding of $L$. anus in the Chasqueiro reservoir, southern Brazil.

\begin{tabular}{|c|c|c|c|}
\hline & Overall average dissimilarity & Average dissimilarity & Contribution $\%$ \\
\hline Summer x Autumn & 61.9 & & \\
\hline Fine particulate matter & & 22.6 & 36.5 \\
\hline Vegetable matter & & 15.3 & 24.7 \\
\hline Summer $\mathrm{x}$ Winter & 50.3 & & \\
\hline Fine particulate matter & & 21.5 & 42.7 \\
\hline Vegetable matter & & 17.6 & 35.1 \\
\hline Summer x Spring & 68.9 & & \\
\hline Fine particulate matter & & 21.7 & 31.5 \\
\hline Organic matter & & 20.2 & 29.2 \\
\hline Autumn $\times$ Winter & 58.5 & & \\
\hline Fine particulate matter & & 21.7 & 37.2 \\
\hline Insects & & 14.5 & 24.8 \\
\hline Autumn x Spring & 72.2 & & \\
\hline Organic matter & & 21.6 & 29.9 \\
\hline Fine particulate matter & & 16.8 & 23.3 \\
\hline Winter x Spring & 70.9 & & \\
\hline Organic matter & & 24.7 & 34.7 \\
\hline Fine particulate matter & & 21.3 & 30.0 \\
\hline
\end{tabular}

\section{DISCUSSION}

\section{Effects of changes in the water level on the $L$. anus diet}

In the present study, no significant variation was found in the feeding behavior of $L$. anus between water levels, although a greater diversity of food items was recorded at low water, when the consumption of FPM increased, being associated with the reduction of the feeding area during the dry season, and the morphology and foraging strategies of the species (Oliveira et al. 2005, Lujan et al. 2012), another potentially important factor is that the fact that the lack of variation among the seasons may be associated with the constant presence of detritus in the environment. That is, although it may increase its availability in certain periods, detritus is a nonlimiting resource. The construction of reservoirs results in a series of impacts on aquatic ecosystems, which affect the connectivity of habitats, community structure, energy flow, and trophic patterns of the species (Corrêa et al. 2015, Winemiller et al. 2014, 2016). The results of the present study indicate that there was a greater abundance of individuals when the water level was low, reflecting the reduction in the area of the reservoir, as observed in previous studies (Agostinho et al. 1997, Bailly et al. 2008, Corrêa 
Table V. Frequency of occurrence $(\% \mathrm{~F})$, numeric frequency $(\% \mathrm{~N})$, area $(\% \mathrm{~A})$ and index of relative importance (\%IRI) for food items consumed by $L$. anus in different size classes collected in the Chasqueiro reservoir, southern Brazil.

\begin{tabular}{|c|c|c|c|c|c|c|c|c|c|c|c|c|c|c|c|c|}
\hline \multirow{2}{*}{ Food items } & \multicolumn{4}{|c|}{ Class $1(n=6)$} & \multicolumn{4}{|c|}{ Class $2(n=7)$} & \multicolumn{4}{|c|}{ Class $3(n=44)$} & \multicolumn{4}{|c|}{ Class $4(n=4)$} \\
\hline & $\% F$ & $\% N$ & $\% A$ & \%IRI & $\% F$ & $\% N$ & $\% A$ & \%IRI & $\% F$ & $\% N$ & $\% A$ & \%IRI & $\% F$ & $\% N$ & $\% A$ & \%IRI \\
\hline Acari & & & & & & & & & 4.5 & 0.4 & $<0.1$ & $<0.1$ & & & & \\
\hline $\begin{array}{c}\text { Algae } \\
\text { filamentous }\end{array}$ & 16.7 & 44.3 & 5.8 & 9.9 & 14.3 & 12.8 & 2.9 & 1.9 & 4.5 & 1.1 & 0.2 & 0.1 & & & & \\
\hline Sand & 33.3 & 0.5 & 8.3 & 3.5 & 42.9 & 2.0 & 8.4 & 3.7 & 15.9 & 0.7 & 1.9 & 0.5 & 25.0 & 0.7 & 12.8 & 4.3 \\
\hline Cladocera & & & & & & & & & & & & & 25.0 & 8.0 & 1.9 & 3.2 \\
\hline Copepoda & & & & & & & & & & & & & 25.0 & 7.3 & 1.7 & 2.9 \\
\hline Diptera (adult) & & & & & & & & & 2.3 & 0.2 & $<0,1$ & $<0.1$ & & & & \\
\hline $\begin{array}{l}\text { Ephemeroptera } \\
\text { (adult) }\end{array}$ & 33.3 & 3.1 & 18.2 & 8.4 & 14.3 & 1.4 & 3.5 & 0.6 & 13.6 & 2.8 & 6.2 & 1.6 & & & & \\
\hline Hemiptera (adult) & 16.7 & 0.3 & 0.1 & 0.1 & & & & & & & & & & & & \\
\hline Coleoptera (larva) & 33.3 & 0.8 & 0.2 & 0.4 & & & & & 15.9 & 8.5 & 1.1 & 2.0 & 25.0 & 11.7 & 4.3 & 5.1 \\
\hline Diptera (larva) & & & & & 14.3 & 0.7 & 0.3 & 0.1 & 2.3 & 0.1 & 0.3 & $<0.1$ & & & & \\
\hline $\begin{array}{c}\text { Fine particulate } \\
\text { matter }\end{array}$ & 100.0 & 1.6 & 49.4 & $60.3^{*}$ & 85.7 & 4.1 & 56.8 & $43.7^{*}$ & 70.5 & 3.0 & 50.1 & $48.9^{*}$ & 75.0 & 2.2 & 33.2 & $34.0^{*}$ \\
\hline Organic matter & 16.7 & 30.6 & 5.8 & 7.2 & 28.6 & 1.4 & 3.6 & 1.2 & 18.2 & 8.4 & 13.7 & 5.2 & 25.0 & 0.7 & 25.6 & 8.4 \\
\hline Vegetable matter & 33.3 & 10.9 & 9.8 & 8.2 & 57.1 & 77.7 & 24.5 & $48.9^{*}$ & 38.6 & 57.8 & 19.0 & $38.8^{*}$ & 25.0 & 13.9 & 4.8 & 6.0 \\
\hline Nemotoda & 16.7 & 0.3 & & 0.1 & & & & & 6.8 & 1.0 & 1.2 & 0.2 & & & & \\
\hline Ostracoda & 16.7 & 0.3 & 0.1 & 0.1 & & & & & 2.3 & 0.3 & $<0.1$ & $<0.1$ & & & & \\
\hline $\begin{array}{l}\text { Palaemonetes } \\
\text { argentinus }\end{array}$ & & & & & & & & & 2.3 & 0.1 & 0.3 & $<0.1$ & & & & \\
\hline $\begin{array}{l}\text { Crustcean } \\
\text { remains }\end{array}$ & & & & & & & & & 4.5 & 2.5 & 1.9 & 0.3 & 25.0 & 3.6 & 4.3 & 2.5 \\
\hline Insect remains & & & & & & & & & 2.3 & 0.1 & 0.3 & $<0.1$ & & & & \\
\hline Seed & 16.7 & 2.6 & 0.7 & 0.6 & & & & & 11.4 & 12.3 & 3.5 & 2.3 & 25.0 & 17.5 & 4.3 & 7.0 \\
\hline Tecameba & 16.7 & 4.9 & 1.6 & 1.3 & & & & & 2.3 & 1.0 & 0.1 & $<0.1$ & 50.0 & 34.3 & 7.3 & $26.6^{*}$ \\
\hline $\begin{array}{c}{ }^{*} \text { Food items } \\
\text { larger importance }\end{array}$ & & & & & & & & & & & & & & & & \\
\hline
\end{tabular}

et al. 2009). As a bottom feeder, L. anus inhabits the benthic zone (Petry \& Schulz 2000) which, together with the low level of the reservoir, facilitated the collection of the specimens.

The composition of the $L$. anus diet recorded in the present study is broadly consistent with the findings of previous studies of the species' diet in the austral region, such as Petry \& Schulz (2000), who described a preference for insect larvae, plant matter, and zooplankton. The ingestion of fine particulate matter, in particular, is a fundamentally important process for the efficient incorporation of nutrients into the trophic chain, through its assimilation by primary consumers(i.e., detritivorous fishes), which are, in turn, consumed by predators (Corrêa et al. 2009, 2012). The fine particulate matter is composed of a range of organisms of autochthonous and allochthonous origin (Jackson et al. 2013), which supports the microbial biota and provides an important resource for the food chain in Neotropical aquatic ecosystems. 

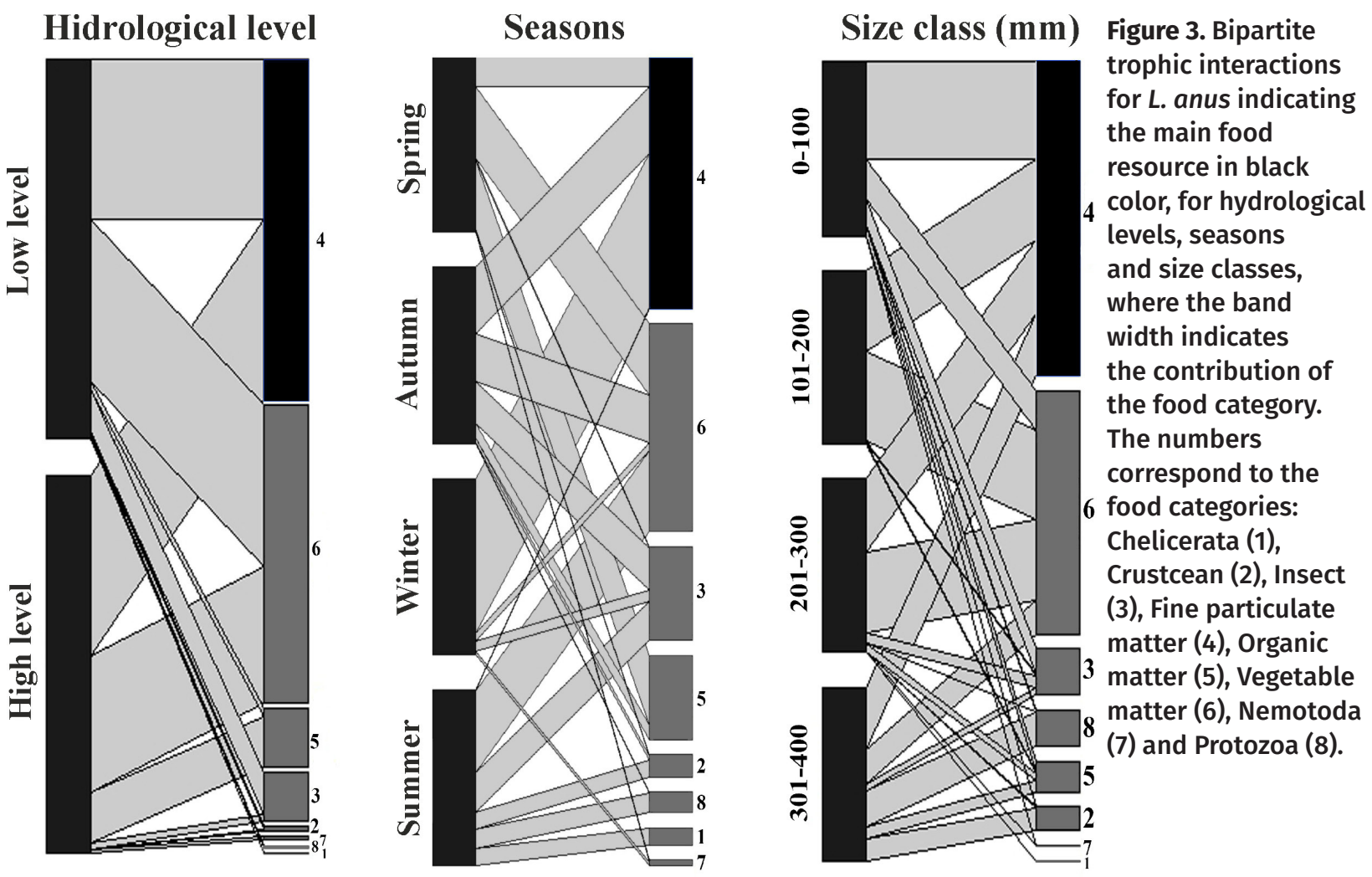

\section{Effects of seasonal variation on the L. anus diet}

The $L$. anus diet varied considerably among the seasons, which may have been related to the hydrological dynamics of the Chasqueiro basin. In the dry season, the reduced flow into the reservoir resulted in a lower input of food items. The reservoir is supplied by two streams, the Chasqueiro and the Chasqueirinho (Corrêa et al. 2015), which transport allochthonous items to the reservoir, especially during the colder months, when rainfall levels increase, leads to an increase in the availability of food items for L. anus. Despite this, L. anus presented a diet consisting basically of fine particulate matter, which is consistent with the findings of Albrecht \& Silveira (2001). During the flood season, plant matter may become more available through the vertical and lateral expansion of the reservoir. In a study of the coastal region of southernmost Brazil, Abreu et al. (2016) recorded a higher input of plant matter during an ENSO (El Niño South Oscillation) event, which triggered an excess of rainfall in the region. It is worth mentioning that the increase in the consumption of insects, in particular those of the order Ephemeroptera, during the spring, may be associated with the increase in temperature during this period, and also the occurrence of the breeding season. Rolla et al. (2009) emphasize that insects are important sources of nutrients, although this resource may vary considerably among seasons, shifting gradually over time.

\section{Effects of ontogenetic variation on the $L$. anus diet}

No variation in the $L$. anus diet was observed among the different ontogenetic classes, however, with similar feeding patterns being observed in immature and adult specimens. This was related in particular to the feeding specialization of the species, as observed in 


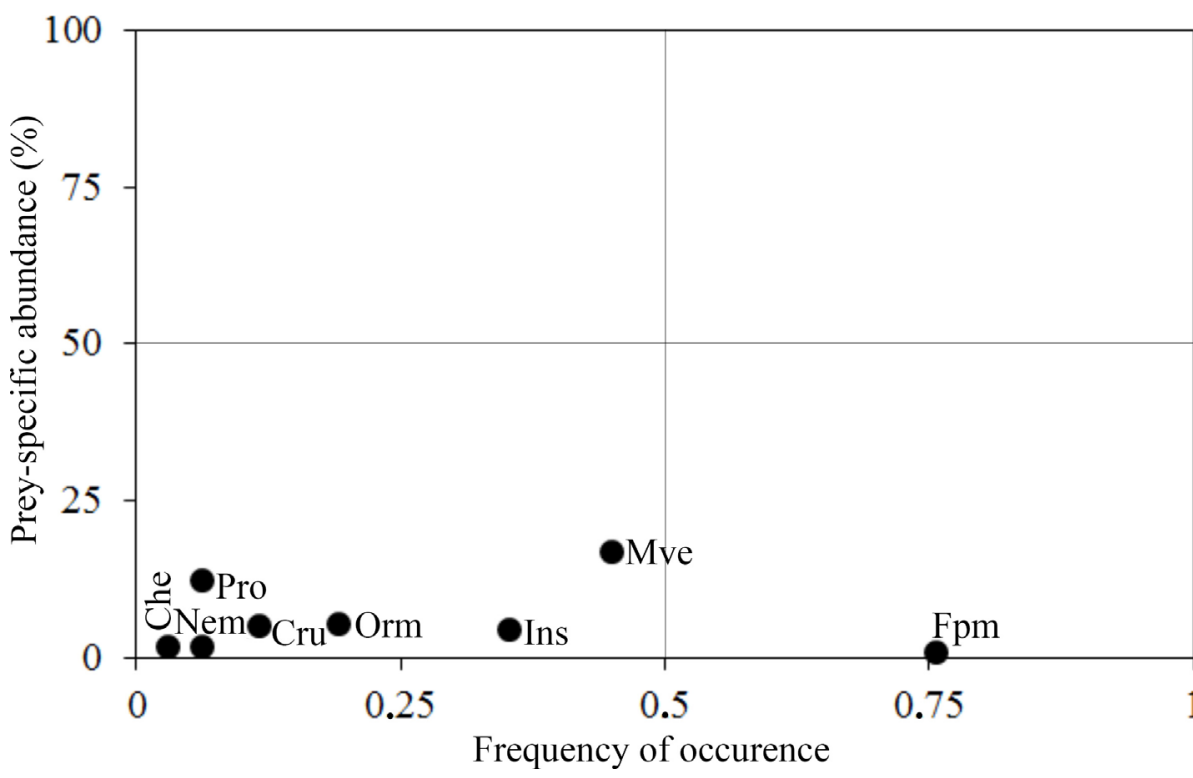

Figure 4. Feeding strategy for population of L. anus studied in the Chasqueiro reservoir, southern Brazil. The codes correspond to the food categories: Che (Chelicerata), Pro (Protozoan), Nem (Nematodea), Cru (Crustacean), Orm (Organic matter), Ins (Insecta), Mve (Vegetable matter) and Fpm (Fine particulate matter). several other fish species from the Neotropical region (Winemiller 1989, Silva 2010, Corrêa et al. 2012). Even so, one important difference is that larger individuals consumed tecameba, which was probably related to the detritivorous diet of the species. As tecamebas are found in the biofilm on the substrate and vegetation of the margins of bodies of water (Souza 2005), the fish may ingest this item accidentally when foraging on these substrates. As L. anus is a widelyexploited fishery resource in the Austral region, laboratory studies based on feeding experiments may provide more conclusive insights into the ontogenetic variation in the diet of this species. Significant ontogenetic variation has been found in the diets of some siluriform species, such as the granulated catfish, Pterodoras granulosus, which was also studied in a Neotropical reservoir (Agostinho et al. 2009). This species undergoes a gradual change in its diet, with the juveniles feeding on allochthonous material derived from the adjacent terrestrial ecosystem, given that they tend to inhabit shallow areas, whereas the adults migrate to deeper areas

\section{Feeding strategy and trophic position}

The feeding strategy of L. anus in the study reservoir was based on a high degree of specialization for the exploitation of fine particulate matter, with the high frequency of this item in the digestive tract of the fish specimens supporting the classification of the species as a detritivorous. Loricariichthys anus has a dorsoventrally flattened body and occurs in the benthic zone of lentic aquatic ecosystems, and, occasionally, in the rapids of some lotic environments (Corrêa et al. 2015). Its buccal apparatus is shaped like a suction cup, located on the inferior surface of the head, which is used to suck or scrape food from substrates, facilitating the ingestion of fine particulate matter (Bowen 1983, Fugi et al. 2001, German \& Miles 2010). Loricariichthys anus also has a long, narrow, and highly sinuous digestive tract, a common morphological feature of many Neotropical detritivorous fish (Bowen, 1983, Corrêa \& Piedras 2008, Pouilly et al. 2003, German \& Miles 2010). Fish species that feed on inorganic particles absorb many nutrientrich items, such as algae and microorganisms 
(Bowen 1983, Garcia et al. 2007, Corrêa \& Piedras 2008, Corrêa et al. 2009).

The Loricariichthys anus is classified in the second trophic level of the food chain due to its consumption of basal food items, with little variation in its trophic position being observed among seasons. Winter and spring were the seasons with the lowest trophic levels, while the summer had the highest level, which was associated with the consumption of insects. Garcia et al. (2006) examined the structure of the food web of Lake Nicola, in southern Brazil, and identified $L$. anus as a secondary consumer that plays an important role in the recycling of nutrients and the transfer of energy to higher trophic levels. Models of trophic position provide valuable insights into the feeding behavior of a species, and how it responds to the seasonal dynamics of the food chain (Zanden \& Rasmussen 1996). In the summer, for example, L. anus presented the highest intake of insects, possibly because this is the period in which most species disperse and reproduce. In particular, dipteran larvae were preyed on only during the summer, which resulted in a singlestep increase in the trophic level of $L$. anus in the food chain. Rolla et al. (2009) concluded that insects are an important nutritional resource for fish, and represent one of the principal trophic links between terrestrial and aquatic environments. The availability and diversity of this resource may vary seasonally, and also in response to anthropogenic impacts and climate change. In general, few fish species are adapted morphologically for the exploitation of the fine particulate matter as a feeding resource, and in the Chasqueiro basin, this niche is almost exclusive to $L$. anus, which means that this catfish may be a keystone species in this reservoir, acting as an important link in the cycling of nutrients and transfer of energy to higher trophic levels. These findings emphasize the importance of this type of study for the understanding of the ecological relationships of the detritivorous fish species found in southern Brazil.

\section{REFERENCES}

ABREU PC, MARANGONI J \& ODEBRECHT C. 2016. So close, so far: differences in long-term chlorophyll a variability in three nearby estuarine coastal stations. Mar Biol Res 16: $1-13$.

AGOSTINHO AA, HAHN NS, GOMES LC \& BINI LM. 1997. Estrutura trófica. In: Vazzoler AEAM, Agostinho AA and Hahn NS (Eds). A planície de inundação do alto rio Paraná: aspectos físicos, biológicos e socioeconômicos, Maringá: EDUEM, p. 229-248.

AGOSTINHO CS, MARQUES EE, OLIVEIRA RJ \& BRAZ PS. 2009. Feeding ecology of Pterodoras granulosus (Siluriformes, Doradidae) in the Lajeado Reservoir, Tocantins, Brazil. Iheringia 99: 301-306.

ALBRECHT MP \& SILVEIRA CM. 2001. Alimentação de Loricariichthys anus (Teleostei: Loricariidae) nas lagoas Marcelino e Peixoto, Planície Costeira do Rio Grande do sul. Acta Limnol Bras 13: 79-85.

AMUNDSEN PA, GABLER HM \& STALDVIK FJ 1996. A new approach to graphical analysis of feeding strategy from stomach contents data - modification of the Costello (1990) method. J Fish Biol 48: 607-614.

ANDERSON MJ. 2005. PERMANOVA: A FORTRAN Computer Program for Permutational Multivariate Analysis of Variance. Department of Statistics, University of Auckland, Auckland.

BAILLY D, AGOSTINHO AA \& SUZUKI HI. 2008. Influence of the flood regime on the reproduction of fish species with different reproductive strategies in the Cuiabá River, upper Pantanal, Brazil. River Res Appl 24: 1218-1229.

BAILLY D, CASSEMIRO FAS, WINEMILLER KO, DINIZ-FILHO JA \& AGOSTINHO AA. 2016. Diversity gradients of Neotropical freshwater fish: evidence of multiple underlying factors in human-modified systems. J Biogeogr 43: 1679-1689.

BOWEN SH. 1983. Detritivory in neotropical fishes' communities. Environ Biol Fishes 9: 137-144.

CLARKE KR. 1993. Non-parametric multivariate analysis of changes in community structure. Aust J Ecol 18: 117-143.

CORRÊA CE, PETRY AC \& HAHN NS. 2009. Influência do ciclo hidrológico na dieta e estrutura trófica da ictiofauna 
do rio Cuiabá, Pantanal Mato-Grossense. Iheringia 99: 456-463.

CORRÊA F, CLAUDINO MC, BASTOS RF, HUCKEMBECK S \& GARCIA AM. 2012. Feeding ecology and prey preferences of a piscivorous fish in the Lagoa do Peixe National Park, a Biosphere Reserve in Southern Brazil. Environ Biol Fishes 93: 1-12.

CORREAA F, OLIVEIRA EF, TUCHTENHAGEN TS, POUEY JLO \& PIEDRAS SRN. 2015. Ichthyofauna of the hydrographic basin of the Chasqueiro Stream (Mirim Lagoon system, southern Brazil): generating subsidies for conservation and management. Biota Neotrop 15: 1-14.

CORRÊA F \& PIEDRAS SRN. 2008. Alimentação de Cyphocharax voga (Hensel, 1869) (Characiformes, Curimatidae) no arroio Corrientes, Pelotas, Rio Grande do Sul, Brasil. Biotemas 21: 117-122.

CORRÊA F, TUCHTENHAGEN TS, OLIVEIRA EF, POUEY JLO \& PIEDRAS SRN. 2014. Distribution extension of Cyphocharax spilotus (Vari, 1987) (Characiformes: Curimatidae), at Patos-Mirim lagoon system, Rio Grande do Sul State, Brazil. Pan-Am J Aquat Sci 9: 43-47.

CORTÉS E. 1997. A critical review of methods of studying fish feeding based on analysis of stomach contents: Application to elasmobranch fishes. Can J Fish Aquat Sci 54: 726-738.

COSTA C, IDE S \& SIMONKA CE. 2006. Insetos Imaturos. Metamorfose e identificação. Ribeirão Preto: Holos, Editora, 249 p.

DELARIVA RS, HAHN NS \& KASHIWAQUI EAL. 2013. Diet and trophic structure of the fish fauna in a subtropical ecosystem: impoundment effects. Neotrop Ichthyol 11: 891-904.

DORMANN CF, FRUEND J, BLUETHGEN N \& GRUBER B. 2009. Indices, graphs and null models: analyzing bipartite ecological networks. Open Ecol J 2: 7-24.

DORMANN CF \& STRAUSS R. 2014. A method for detecting modules in quantitative bipartite networks. Methods Ecol Evol 5: 90-98.

FERREIRA FS, VICENTIN W, COSTA FES \& SÚAREZ YR. 2014. Trophic ecology of two piranha species, Pygocentrus nattereri and Serrasalmus marginatus (Characiformes, Characidae), in the floodplain of the Negro River, Pantanal. Acta Limnol Bras 26: 381-391.

FONTOURA NF, VIEIRA JP, BECKER FG, RODRIGUES LHR, MALABARBA LR, SCHULZ UH, MOLLER JR OO, GARCIA AM \& VILELLA FS. 2016. Aspects of fish conservation in the upper Patos Lagoon basin. J Fish Biol 89: 315-336.
FUGI R, AGOSTINHO AA \& HAHN NS. 2001. Trophic morfology of five benthic feeding fish species of a tropical floodplain. Rev Bras Biol 61: 27-33.

FUGI R, HAHN NS \& AGOSTINHO AA. 1996. Feeding styles of five species of bottom-feeding fishes of the high Paraná River. Environ Biol Fishes 46: 297-307.

GARCIA AM ET AL. 2017. Hydrologic pulsing promotes spatial connectivity and food web subsidies in a subtropical coastal ecosystem. Mar Ecol Prog Ser 567: 17-28.

GARCIA AM, HOEINGHAUS DJ, VIEIRA JP \& WINEMILLER KO. 2007. Isotopic variation of fishes in freshwater and estuarine zones of a large subtropical coastal lagoon.Estuar Coast Shelf Sci 3: 399-408.

GARCIA AM, HOEINGHAUS DJ, VIEIRA JP, WINEMILLER KO, MARQUES DMLM \& BEMVENUTI MA. 2006. Preliminary examination of food web structure of Nicola Lake (Taim Hydrological System, south Brazil) using dual C and N stable isotope analyses. Neotrop Ichthyol 2: 279-284.

GARCIA AM, VIEIRA JP \& WINEMILLER KO. 2001. Dynamics of the shallow-water fish assemblage of the Patos Lagoon estuary (Brazil) during cold and warm ENSO episodes. J Fish Biol 59: 1218-1238.

GERKING SD. 1994. Feeding Ecology of Fish. Academic Press, San Diego, 416 p.

GERMAN DP \& MILES RD. 2010. Stable carbon and nitrogen incorporation in blood and fin tissue of the catfish Pterygoplichthys disjunctivus (Siluriformes, Loricariidae). Environ Biol Fishes 89: 117-133.

GIORA J, FIALHO CB \& DUFECH APS. 2005. Feeding habit of Eigenmannia trilineata Lopez \& Castello, 1966 (Teleostei: Sternopygidae) of Parque Estadual de Itapuã, RS, Brazil. Neotrop Ichthyol 3: 291-298.

HAHN NS, PAVANELLI CS \& OKADA EK. 2000. Dental development and ontogenetic diet shifts of Roeboides paranensis Pignalberi (Osteichthyes, Characinae) in pools of the upper Rio Paraná. Rev Bras Biol 60: 93-99.

HYSLOP EJ 1980. Stomach contents analysis - a review of methods and their application. J Fish Biol 17: 411-429.

JACKSON AT, ADITE A, ROACH KA \& WINEMILLER KO. 2013. Primary production, food web structure, and fish yields in constructed and natural wetlands in the floodplain of an African river. Can. J Fish Aquat Sci 70: 543-553.

JARQUE CM \& BERA AN. 1987. A teste for normality of observation and regression residuals. Int Stat Rev 55: 163-172.

JUNK WJ. 1980. Áreas inundáveis: um desafio para limnologia. Acta Amaz 10: 775-795. 
KEENE JL, NOAKES DL, MOCCIA RD \& SOTO CG. 1998. The efficacy of clove oil as an anaesthetic for rainbow trout, Oncorhynchus mykiss (Walbaum). Aquac Res 29: 89-101.

LUJAN NK, WINEMILLER KO \& ARMBRUSTER JW. 2012. Trophic diversity in the evolution and community assembly of loricariid catfishes. BMC Evol Biol 12: 124.

MALABARBA LR, CARVALHO NP, BERTACO VA, CARVALHO TP, SANTOS JF \& ARTIOLI LGS. 2013. Guia de Identificação dos Peixes da Bacia do Rio Tramandaí. 1a ed., Porto Alegre: Via Sapiens, $140 \mathrm{p}$.

MARTINS MM, MENDONÇA HS, RODRIGUES SS \& ARAÚJO FG. 2017. Trophic ecology of two syntopic sciaenid species (Micropogonias furnieri (Desmarest, 1823) and Ctenosciaena gracilicirrhus) (Metzelaar, 1919) in a tropical bay in south-eastern Brazil. J Appl Ichthyol 33: 740-745.

MENEZES M \& BICUDO CEM. 2006. Gêneros de Algas de Águas Continentais do Brasil: chave para identificação e descrições. São Carlos: Rima, 2006. v. 1, 502 p.

MUGNAI R, NESSIMIAN JL \& BAPTISTA DF. 2010. Manual de identificação de macroinvertebrados Aquáticos do estado do Rio de Janeiro: Technical Books, 176 p.

OLIVEIRA EF, MINTE-VERA CV \& GOULART E. 2005. Structure of fish assemblages along spatial gradients in a deep subtropical reservoir (Itaipu Reservoir, Brazil-Paraguay border). Environ Biol Fishes 72: 283-304.

OLIVEIRA MCLM, BASTOS RF, CLAUDINO MC, ASSUMPÇÃO CM \& GARCIA AM. 2014. Transport of marine-derived nutrients to subtropical freshwater food webs by juvenile mullets: a case study in southern Brazil Aquat Biol 20: 91-100.

PAULY D \& CHRISTENSEN V. 2000. Trophic levels of fishes. In: Froese R and Pauly D (Eds). FishBase 2000: Concepts, Design and Data Sources. ICLARM, Manila, 181 p.

PAULY D, FROESEN R, SA-A PS, PALOMARES ML, CHRISTENSEN V \& RIUS J. 2000. TrophLab Manual. Iclarm, Manila.

PAULY D \& PALOMARES ML. 2000. Approaches for dealing with three sources of bias when studying the fishing down marine food web phenomenon. In: Briand $F(E d)$. Fishing Down the Mediterranean Food Webs? CIESM Workshop Series 12: 61-66.

PERALTA-MARAVER I, ROBERTSON AL, REZENDE EL, LEMES-SILVA AL, TONETTA D, LOPES M, SCHMITT R, LEITE NK, NUÑER A \& PETRUCIO MM. 2017. Winter is coming: food web structure and seasonality in a subtropical freshwater coastal-lake. Ecol Evol 7: 1-9.

PERETTI D \& ANDRIAN IF. 2004. Trophic structure of fish assemblages in five permanent lagoons of the high
Paraná River floodplain, Brazil. Environ Biol Fishes 71: 95-103.

PETRY AC \& SCHULZ UH. 2000. Ritmo de alimentação de juvenis de Loricariichthys anus (Siluriformes, Loricariidae) da lagoa dos Quadros, RS, Brasil. Iheringia 89: 171-176.

PINKAS L, OLIPHANT MS \& IVERSON ILK 1971. Food habits of albacore, bluefin tuna, and bonito in California waters. Calif Fish Game Fish Bull 152: 1-105.

POUILLY M, LINO F, BRETENOUX JG \& ROSALES C. 2003. Dietary morphological relationships in a fish assemblage of the Bolivian Amazonian floodplain. J Fish Biol 62: 1137-1158.

QUIRINO BA, CARNIATTO N, GUGLIELMETTI R \& FUGI R. 2017. Changes in diet and niche breadth of a small fish species in response to the flood pulse in a Neotropical floodplain lake. Limnologica 62: 126-131.

REIS RE \& PEREIRA EHL. 2000. Three new species of the loricariid catfish genus Loricariichthys (Teleostei: Siluriformes) from southern South America. Copeia 22: 1029-1047.

REIS RE, ALBERT JS, DI DARIO F, MINCARONE MM, PETRY P \& ROCHA LA. 2016. Fish biodiversity and conservation in South America. J Fish Biol 89: 12-47.

ROACH KA, WINEMILLER KO \& DAVIS SE. 2014. Autochthonous production in shallow littoral zones of five floodplain rivers: effects of flow, turbidity, and nutrients. Freshwater Biol 59: 1278-1293.

ROLLA APPR, ESTEVES KE \& ÁVILA-DA-SILVA AO. 2009. Feeding ecology of a stream fish assemblage in an Atlantic Forest remnant (Serra do Japi, SP, Brazil). Neotrop Ichthyol 7: 65-76.

SILVA JM, HERNANDEZ-BLAZQUEZ FJ \& JULIO JR. 1997. A new accessory respiratory organ in fishes: morphology of the respiratory burses of Loricariichthys platymetopon (Pisces, Loricariidae). Ann Sci Nat Zool Biol Anim 18: 94-103.

SILVA MJ, FIGUEIREDO BRS, RAMOS RTC \& MEDEIROS ESF. 2010. Food resources used by three species of fish in the semi-arid region of Brazil. Neotrop Ichthyol 8: 825-833.

SONDOTÉCNICA SA. 1976. Distrito de Irrigação do Arroio Chasqueiro. Sumário. Estudo realizado para a SUDESUL$\mathrm{MI}, 46 \mathrm{p}$.

SOUTO AC, VIDOTTO-MAGNONI AP, BRANDÃO H, RAMOS IP \& CARVALHO ED. 2011. Actinopterygii, Siluriformes, Loricariidae, Loricariichthys platymetopon Isbrücker and Nijssen, (1979): First record in Reservoir of Canoas II, 
Middle Paranapanema River, border of the states of São Paulo and Paraná, Brazil. Check List 7: 279-281.

SouzA MBG. 2005. Tecamebas (Protozoa Rhizopoda) associadas às macrófitas aquáticas da bacia do rio Jequitinhonha: Parque Estadual do Rio Preto e Parque Estadual do Grão Mogol, MG. Unimontes Cientifica 7: 1-14.

STERGIOU KI \& KARPOUZI VS. 2002. Feeding habits and trophic levels of Mediterranean fish. Rev Fish Biol Fisher 11: $217-254$.

VITAL-RODRÍGUEZ BE, RAMÍREZ-HERREJÓN JP, MONCAYOESTRADA R, CARAVEO-PATIÑO J \& DOMÍNGUEZ-DOMÍNGUEZ O. 2017. Feeding strategy of silverside species in eutrophic Lake Pátzcuaro, Mexico. J Appl Ichthyol 33: 93-101.

WESNER JS \& BELK MC. 2015. Variation in the trophic position of common stream fishes and its relationship to the presence of a rare fish, northern leatherside chub (Lepidomeda copei). Ecol Freshw Fish 24: 234-241.

WINEMILLER KO. 1989. Ontogenetic diet shifts and resource partitioning among piscivorous fishes in the Venezuelan llanos. Environ Biol Fishes 26: 177-199.

WINEMILLER KO. 1990. Spatial and Temporal Variation in Tropical Fish Trophic Network. Ecol Monogr 60: 331-367.

WINEMILLER KO ET AL. 2016. Balancing hydropower and biodiversity in the Amazon, Congo, and Mekong Basinscale planning is needed to minimize impacts in megadiverse rivers. Science 351: 128-129.

WINEMILLER KO, MONTAÑA CG, ROELKE DL, COTNER JB, MONTOYA JV, SANCHEZ L, CASTILLO MM \& LAYMAN CG. 2014. Pulsing hydrology determines top-down control of basal resources in a tropical river-floodplain ecosystem. Ecol Monogr 84: 621-635.

YOUSON JH \& Al-MAHROUKI AA. 1999. Ontogenetic and Phylogenetic Development of the Endocrine Pancreas (Islet Organ) in Fishes. Gen Comp Endocrinol 116: 303-335.

ZANDEN MJV \& RASMUSSEN JB. 1996. A trophic position model of pelagic food webs: impact on contaminant bioaccumulation in lake trout. Ecol Monogr 66: 451-477.

ZAR JH. 1996. Biostatistical Analysis, $4^{\text {th }}$ ed., New Jersey: Prentice Hall, 960 p.

ZAWADZKI CH, OLIVEIRA AS, DE OLIVEIRA RR \& RAPP PY-DANIEL LH. 2015. Hypostomus melanephelis, a new armored catfish species from the rio Tapajós basin, Brazil (Teleostei: Loricariidae). Ichthyol Explor Fres 26: 49-58.

ZAWADZKI CH, SILVA HP \& TROY WP. 2018. Redescription of Hypostomus latirostris (Regan, 1904) with the recognition of a new species of Hypostomus (Siluriformes:
Loricariidae) from the upper rio Paraguay basin, Brazil. Ichthyol Explor Fres. 1079: 1-18.

\section{How to cite}

CORRÊA F, TUCHTENHAGEN TS, POUEY J, PIEDRAS SRN \& OLIVEIRA EF. 2021. Trophic ecology of Loricariichthys anus (Valenciennes, 1835), (Loricariidae: Loricariinae) in a subtropical reservoir, Rio Grande do Sul, Brazil. An Acad Bras Cienc 93: e20200438. DOI 10.1590/00013765202120200438 .

Manuscript received on March 30, 2020;

accepted for publication on August 3, 2020

FABIANO CORRÊA ${ }^{1}$

https://orcid.org/0000-0003-1909-5137

\section{THIAGO S. TUCHTENHAGEN ${ }^{2}$}

https://orcid.org/0000-0001-6528-7311

\section{JUVÊNCIO POUEY}

https://orcid.org/0000-0002-5740-4466

\section{SÉRGIO R.N. PIEDRAS ${ }^{2}$}

https://orcid.org/0000-0002-8647-4105

\section{EDSON F. DE OLIVEIRA 3}

https://orcid.org/0000-0002-4224-6565

${ }^{1}$ Programa de Pós-Graduação em Ecologia e Conservação, Universidade do Estado de Mato Grosso, Campus Nova Xavantina, Av. Dr. Renato Figueiro Varella, Caixa Postal 08, 78690-000 Nova Xavantina, MT, Brazil

${ }^{2}$ Universidade Federal de Pelotas, Laboratório de Ictiologia, Campus Capão do Leão, s/n, 96160-000 Capão do Leão, RS, Brazil

${ }^{3}$ Universidade Federal Tecnológica do Paraná, Laboratório de Ecologia Teórica e Aplicada, Campus Londrina, Avenida Pioneiros, Caixa Postal 3131, 86036-370 Londrina, PR, Brazil

Correspondence to: Fabiano Corrêa

E-mail:correafecologia@yahoo.com.br

\section{Author contributions}

Fabiano Corrêa and Thiago dos Santos Tuchtenhagen conducted the fieldwork and in the laboratory, performed the data analysis, interpreted the results and wrote the manuscript. Juvêncio Pouey, Sérgio Renato Noguez Piedras and Edson Fontes de Oliveira, interpreted the results and wrote the manuscript.

\section{(cc) BY}

